\title{
WATER QUALITY MODELLING TO PREDICT BOD AND TP LOADS OF DURIANGKANG DAM
}

\author{
Calvin Wimordi ${ }^{*}$, Doddi Yudianto ${ }^{1}$, Guan Yiqing ${ }^{2}$ \\ ${ }^{1}$ Department of Civil Engineering, Universitas Katolik Parahyangan, Bandung, Indonesia \\ ${ }^{2}$ College of Hydrology and Water Resources, Hohai University, Nanjing 210098, China
}

(Received: July 2020 / Revised: August 2020 / Accepted: September 2020)

\begin{abstract}
Water quality modeling is highly needed to predict and to identify the water quality alteration and distribution along the water body. Besides that, water quality modeling also can be used to predict the pollutant load if there is no data recording. The water quality analysis simulation program (WASP) will be used in this study to forecast domestic load, in particular BOD and TP loads in Duriangkang Dam. Initially, the estimated load is obtained based on the previous study that being extended by using a linear regression line. After that, the estimated load is calibrated according to the results of the water test. The WASP model is simulated for a period of 3 years from 1 January 2016 to 31 December 2018 and is divided into 2 processes, namely calibration and verification process. The calibration process is carried out in the first two years, followed by the verification process for the remainder of the year. The calibration and verification process are measured by objective functions, namely RMSE and the percentage difference. According to the simulation results, the objective functions provide satisfying findings, which means that the predicted BOD and TP loads for Duriangkang Dam during that time are accurate.
\end{abstract}

Keywords: Domestic Load; Calibration; Verification; WASP; Duriangkang Dam

\section{INTRODUCTION}

Over the past few decades, water quality modeling has been one of the essential roles to restore and preserve the quality of the water. In addition, it becomes a tool in managing, planning, and controling pollution for government agencies, local authorities, and other entities regulating water supplies (Mateus et al., 2018). The model is expected to predict water quality and its relationships to environmental factors in water sources such as rivers, lakes, and reservoirs. The understanding of processes in the environment is the most imporatant factor and has an impact on the accuracy of the environmental models. On the other hand, the availability of water quality data also affects its accuracy. The function of the data, in addition to being an input, is often used to calibrate and vaildate the model. Model calibration is the process by which estimates of model parameters are obtained by comparing field observations and model predictions. At the same time, the verification includes checking calibrated model against the additional set of field data, preferably under different environmental conditions, in order to further examine the range of validity of the calibrated model (Himesh, 2000).

*Corresponding author's email: calvinwimordi@gmail.com, Tel. +62 89615893640

DOI: https://doi.org/10.32783/csid-jid.v3i2.145 
Nowadays, there are a number of water quality models and selecting suitable model needs to consider some requirements and its capability to model many water bodies. Process-based models are suitable methods for quantifying nutrients in a water body, using well-established physical relationships between nutrient availability and algal uptake kinetics, and other site-specific dependencies such as light, streamflow, temperature, to elicit tangible relationships between nutrient concentrations and biologic or water quality responses (Flynn \& Suplee, 2011). WASP or water quality analysis simulation program is one of the most common models to forecast water quality and process-based models, or mechanistic or deterministic water quality models (Moses et al., 2015).

US EPA as the public domain produces the WASP model and aims to forecast the water quality of surface water in lakes, reservoirs, and rivers. WASP is one of the most commonly used programs to address water quality issues (Balcerzak, 2006). WASP has also been used and implemented in several lakes or reservoirs, such as those investigated by Ernst \& Owens in (2009) on a large Texas reservoir; Moses et al. in (2015) on the Akkulam-Veli Lake; and Larico \& Medina in (2019) on El Pane Reservoirs. Previous study found that WASP is highly accurate for advanced water quality modeling. Therefore, this study will employ the WASP model to simulate the consistency of the water quality in the Duriangkang Dam to obtain the BOD and TP loads.

\section{DESCRIPTION OF STUDY AREA AND DATA AVAILABILITY}

\subsection{General Description of Duriangkang Dam}

Geographically, the Duriangkang Dam is located in Bagan Village, Seibeduk Sub-district, Batam City, Riau Island Province with coordinate of $01^{\circ} 02^{\prime} 24^{\prime \prime} \mathrm{N}$ and $104^{\circ} 05^{\prime} 11^{\prime \prime}$ E. Duriangkang Dam was built between 1992 to 1995 and has become Indonesia's first and largest estuary dam with a total effective volume of about 107,000,000 m3. It is equipped with a weir at the downstream segment, and the inundation area at elevation $+7.5 \mathrm{~m}$ is $24.6 \mathrm{~km} 2$. The Duriangkang Dam plays a vital role in supplying three $\mathrm{m} 3 / \mathrm{s}$ of clean water to Batam City.

Based on a study conducted by Willy et al. (2019), the Duriangkang Dam receives inflow from the upper rivers of Duriangkang Catchment and outflow of Muka Kuning Dam that creates a cascade dam system. For water quality boundaries, the upper rivers are presumed to have a value close to Indonesia's Class II raw water standard, while the outflow of Muka Kuning Dam is based on the available data in 2015. In actual condition, the Duriangkang Dam receives domestic wastewater, industrial wastewater, and a variety of fish farms. However, the industrial wastewater loads in this research is neglected, and domestic loads and fish farms are simplified to BOD and TP loads only. In addition, the output of this model is the total BOD and TP loads without load distribution for each domestic load and fish farm load.

\subsection{Data Availability}

As a source of clean water, the water is sampled and tested annually on 1 October in 2016, 2017, and 2018 respectively. The water was taken at a depth of $2 \mathrm{~m}$ and the water elevation was reported on $+4.5 \mathrm{~m},+6.70 \mathrm{~m}$, and $+6.30 \mathrm{~m}$, respectively (See Figure 1). During the sampling, the water was taken in a cloudy condition, and the weather was sunny. Sampling water was collected using a sampler bottle, and several parameters are measured on sites such as temperature, $\mathrm{pH}, \mathrm{DO}$, conductivity, and turbidity. In 2016, sampling was taken on dry season (started from 2014 to 2016), and opposite season in 2017 and 2018. In this study, only BOD and TP were observed using the comparison data as shown in Table 1. 


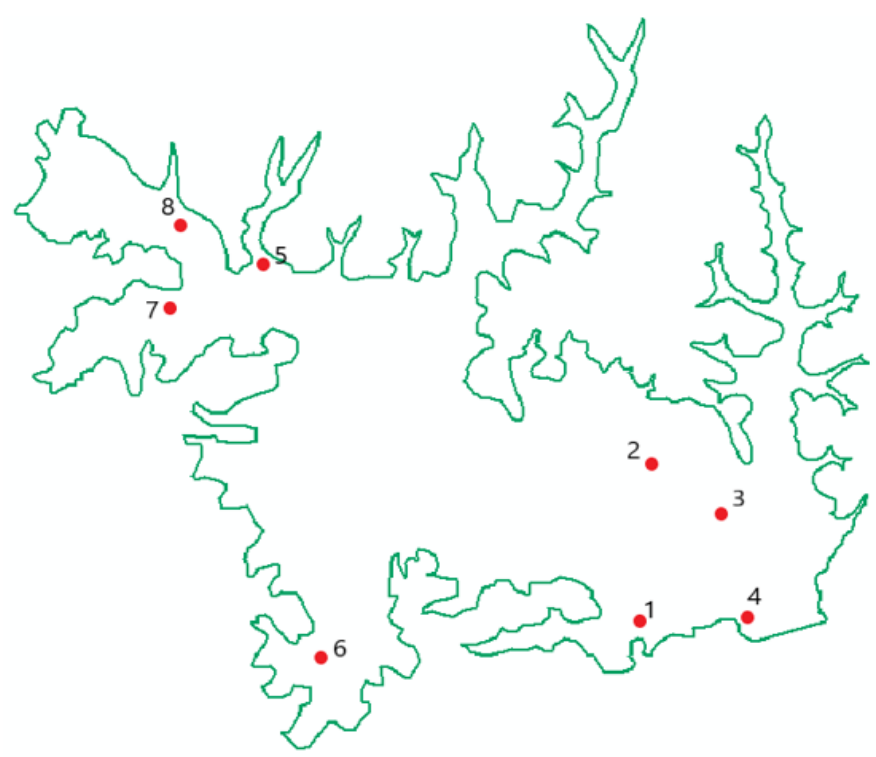

Figure 1. Sampling location

In addition to the data on water quality, both geometry and climate data will also be used in this study. The geometry data is based on the bathymetry map, while the climate data considers rainfall, wind speed, water temperature, and solar radiation data. The rainfall data used measurements at the rainfall station in Hang Nadim Airport in Batam City. Data on wind speed and water temperature are obtained from reports issued by the Indonesian Meteorology, Climatology, and Geophysical Agency, while data on solar radiation is obtained from the NASA POWER Data Access View.

Table 1 . The findings of the water quality test

\begin{tabular}{|c|c|c|c|c|c|c|c|c|c|c|c|c|}
\hline \multirow[b]{2}{*}{ Location } & \multicolumn{3}{|c|}{2016} & \multicolumn{3}{|c|}{2017} & \multicolumn{3}{|c|}{2018} & \multicolumn{3}{|c|}{$\begin{array}{c}\text { Water Quality } \\
\text { Standard Class II }\end{array}$} \\
\hline & DO & $\mathrm{TP}$ & BOD & DO & $\mathrm{TP}$ & $\begin{array}{r}\text { BOD } \\
(\mathrm{m}\end{array}$ & $\begin{array}{l}\mathrm{DO} \\
\mathrm{z} / \mathrm{L})\end{array}$ & $\mathrm{TP}$ & BOD & DO & $\mathrm{TP}$ & BOD \\
\hline 1 & 3.3 & 11.8 & 26.0 & 6.4 & 1.9 & 10.0 & 7.2 & $<0.1$ & 4.7 & \multirow{8}{*}{4} & \multirow{8}{*}{0.2} & \multirow{8}{*}{3} \\
\hline 2 & 3.0 & 16.4 & 39.0 & 5.0 & 1.3 & 38.0 & 6.1 & $<0.1$ & 4.2 & & & \\
\hline 3 & 3.2 & 13.9 & 26.0 & 6.3 & 1.6 & 11.0 & 5.3 & $<0.1$ & 12.4 & & & \\
\hline 4 & 3.3 & 9.0 & 27.0 & 6.3 & $<0.1$ & 10.0 & 6.5 & $<0.1$ & 4.5 & & & \\
\hline 5 & 3.2 & 12.1 & 28.0 & 6.0 & 1.2 & 11.0 & 6.0 & 0.1 & 7.5 & & & \\
\hline 6 & 3.5 & 11.7 & 32.0 & 6.1 & 1.2 & 12.0 & 5.4 & 0.2 & 8.4 & & & \\
\hline 7 & 3.3 & 10.7 & 27.0 & 6.2 & 1.2 & 11.0 & 5.6 & 0.2 & 7.2 & & & \\
\hline 9 & 3.0 & 17.6 & 30.0 & 6.3 & 1.8 & 10.0 & 5.7 & 0.2 & 12.3 & & & \\
\hline
\end{tabular}

\subsection{Water Quality Analysis Simulation Program (WASP)}

WASP was initially developed by the United States Environmental Protection Agency (US EPA). WASP version 8.32 is the most up to date version and will be used for the research purposes. The current WASP was an improvement of the original WASP (Ambrose et al., 1988; Connolly 
\& Winfield, 1984; Di Toro et al., 1983) and this model helps users interpret and predict water quality response to natural phenomena and manmade emissions for different management decisions. WASP consists of two kinetic sub-programs called EUTRO and TOXI designed to simulate issues related to water quality. EUTRO enables the modelling of water relate to eutrophication indicators (DO, BOD, nutrient concentration, and phytoplankton), while TOXI simulate toxic pollutants (COD and heavy metals). The fundamental concept of hydrodynamics and water quality program relate to the conservation of mass, as shown in Equation 1 below:

$$
\frac{\partial C}{\partial \mathrm{t}}(A C)=\frac{\partial}{\partial x}\left(-U_{x} A C+E_{x} A \frac{\partial C}{\partial x}\right)+A\left(S_{L}+S_{B}\right)+A S_{K}
$$

where:

C : concentration of the water quality constituent $\left(\mathrm{mg} / \mathrm{L}\right.$ or $\left.\mathrm{g} / \mathrm{m}^{3}\right)$

t : time (days)

Ux : longitudinal advective velocities (m/day)

Ex : longitudinal diffusion coefficients $\left(\mathrm{m}^{2} /\right.$ day $)$

A : cross-sectional area $\left(\mathrm{m}^{2}\right)$

$\mathrm{SL} \quad$ : direct and diffuse loading rate $\left(\mathrm{g} / \mathrm{m}^{3}\right.$-day)

SB : boundary loading rate (upstream, downstream, benthic, and atmospheric $\left(\mathrm{g} / \mathrm{m}^{3}\right.$-day)

SK : total kinetic transformation rate; positive is source, negative is $\operatorname{sink}\left(\mathrm{g} / \mathrm{m}^{3}\right.$-day)

The WASP adopts model network as a set of expanded control volumes or "segments" that together represent the physical configuration of the water body. The network may subdivide the water body laterally, vertically and longitudinally. Concentrations of water quality constituents are measured within each segment. The ttransport rates of water quality constituents are calculated across the interface of the adjacent segment.

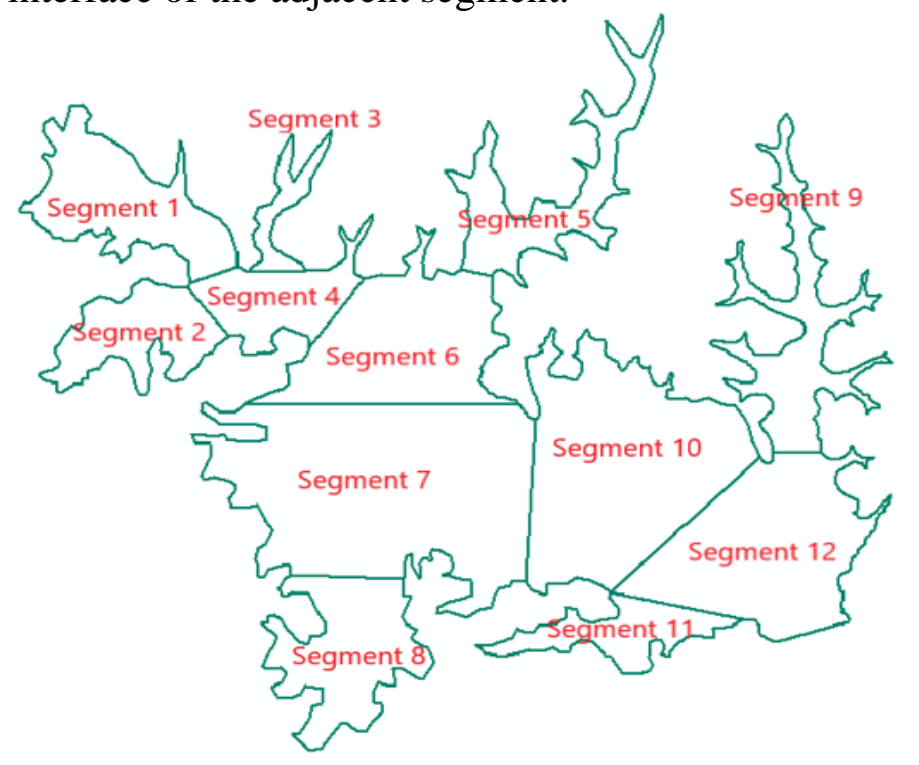

Figure 2. Duriangkang Dam segmentation in WASP 
Since the WASP model works by segments, the Duriangkang Dam divided into 12 segments (See Figure 2). Each segment divided based on the inflow discharge and location of water sampling. However, due to uneven location of the sampling point, a segment without point of location will use their closest one. The geometry of each segment is derived from the bathymetry data and presented in Table 2.

Table 2. Geometry data

\begin{tabular}{rlrr}
\hline \multirow{2}{*}{ No } & \multirow{2}{*}{ Segment name } & Length & \multicolumn{1}{c}{ width } \\
\cline { 3 - 4 } & & \multicolumn{1}{c}{$\mathrm{m}$} & \multicolumn{1}{c}{$\mathrm{m}$} \\
\hline 1 & Segment 1 & 2740.85 & 440.16 \\
2 & Segment 2 & 1293.89 & 565.82 \\
3 & Segment 3 & 809.89 & 157.12 \\
4 & Segment 4 & 1212.86 & 513.11 \\
5 & segment 5 & 2740.3 & 480.2 \\
6 & Segment 6 & 1227 & 1889.92 \\
7 & Segment 7 & 1952.65 & 1117.09 \\
8 & Segment 8 & 1381.76 & 826.47 \\
9 & Segment 9 & 1452.7 & 233.74 \\
10 & Segment 10 & 2197.1 & 992.65 \\
11 & Segment 11 & 1410.8 & 864.3 \\
12 & Segment 12 & 819.3 & 1780.2 \\
\hline
\end{tabular}

Global data for the slope and bottom roughness are 0.001 and 0.04 . The simulation in the WASP model consist of calibration and verification processes. The calibration process is conducted from 1 January, 2016 to 31 December 2017, and the verification process simulated from 1 January 2018 to 31 December 2018. The calibration evaluated by using Root Mean Square Error (RMSE), while the verification processed using a percentage difference. The latter was used due to limited data for comparison. In the WASP model, the transport method for the upper rivers, the outflow of Muka Kuning Dam, and each dam segment is using a 1D kinematic wave except at the downstream segment (Segment 12) that use Ponded Weir. It is assumed that the dispersion is longitudinal and calculated by using following equation (Bowie et al., 1985):

$$
D_{h}=A_{d} \times L^{\frac{4}{3}}
$$

where:

$D_{h} \quad$ : horizontal dispersion $(\mathrm{cm} 2 / \mathrm{s})$

$A_{d} \quad$ : dissipation parameter (conventionally $0.005 \mathrm{~cm} / \mathrm{s}$ )

$\mathrm{L} \quad$ : average distance $(\mathrm{cm})$ between segments

\section{RESULTS}

The load (See Table 3) is initially estimated on the basis of the previous study (Hariyadi, 2006). The study predicts the BOD5 load for Duriangkang Dam from 2001 to 2010 by using dataset from 1992 to 2000. There are a range of factors affecting the prediction, such as domestic land use, clean water demand, and domestic wastewater discharge. In this research, results from the 
previous study will be used by taking into account a linear regression to obtain the BOD loads in 2016, 2017, and 2018. This study assumed the BOD 5 from previous study as the BOD ultimate. The results from linear regression indicated an annual increase of BOD loads (see Table 3 ). In general, the rise in domestic load would be followed by an increase in the total population. This evidence can be seen by the increasing population of Batam City, and on a smaller scale, the total population of Seibeduk-Subdistrict (Table 4).

Table 3. Estimated load

\begin{tabular}{rrrr}
\hline Year & $\begin{array}{c}\text { Domestic waste load } \\
\left(\mathrm{kgBOD}_{5} / \text { day }\right)\end{array}$ & Year & $\begin{array}{r}\text { Domestic waste load } \\
\left(\mathrm{kgBOD}_{5} / \text { day }\right)\end{array}$ \\
\hline 1992 & 148.44 & 2002 & 1624.05 \\
1993 & 237.17 & 2003 & 1771.6 \\
1994 & 271.08 & 2004 & 1919.15 \\
1995 & 389.64 & 2005 & 2066.7 \\
1996 & 540.55 & 2006 & 2214.25 \\
1997 & 847.09 & 2007 & 2361.8 \\
1998 & 1084.26 & 2008 & 2509.35 \\
1999 & 1321.43 & 2009 & 2656.9 \\
2000 & 1457 & 2010 & 2804.45 \\
2001 & 1476.5 & & \\
\hline
\end{tabular}

Initially, the estimated load from Table 3 is entered and simulated in the WASP model and the results compared with the observed data. According to the initial simulation, the results are not satisfactory, and a calibration then required. The test results showed annual improvement of water quality, especially in 2017 and 2018.

Table 4. Estimated population of Batam City and Seibeduk-Subdistrict

\begin{tabular}{cccc}
\hline Year & Batam City & Year & Seibeduk-Subdistrict \\
\hline 2010 & 954,450 & 2010 & 82,903 \\
2011 & $1,000,661$ & 2015 & 85,919 \\
2012 & $1,047,534$ & 2016 & 86,691 \\
2013 & $1,094,623$ & 2017 & 87,386 \\
2014 & $1,141,816$ & & \\
2015 & $1,188,985$ & & \\
2016 & $1,236,399$ & & \\
2017 & $1,283,196$ & & \\
2018 & $1,329,773$ & & \\
2019 & $1,376,009$ & & \\
2020 & $1,421,961$ & & \\
\hline
\end{tabular}

(Source: BPS, 2015; 2017; 2018) 
In addition, the seasonal effects also lead to some improvement. The dry season in 2016 deteriorated water levels and started to improve during rainy seasons in 2017 and 2018. In order to improve the model accuracy, the estimated load must be re-calibrated. Based on the test results, the BOD and TP concentrations are greatly improved, and now the estimated load is re-calibrated accordingly shown in Table 5.

Table 5. Load calibration

\begin{tabular}{ccc}
\hline Year & $\begin{array}{c}\text { BOD } \\
(\mathrm{kg} / \text { day })\end{array}$ & $\begin{array}{c}\text { TP } \\
(\mathrm{kg} / \text { day })\end{array}$ \\
\hline 2016 & 3945.92 & 2258.04 \\
2017 & 1165.07 & 240.38 \\
2018 & 722.95 & 27.12
\end{tabular}

Besides the load, environmental parameters are also calibrated simultaneously. The reaeration coefficient, BOD decay rate @ $20{ }^{\circ} \mathrm{C}$ and mineralization rate constant for dissolved organic phosphorus @20 ${ }^{\circ} \mathrm{C}$, were found to have values of 1.07 - 1.60 day $^{-1}, 0.01$ day $^{-1}$, and 0.04 day $^{-}$ ${ }^{1}$ respectively. The temperature correction for the decay rate of BOD and dissolved organic phosphorus mineralization is 1.047 .

Table 6. Evaluation results for calibration and verification process

\begin{tabular}{ccccc}
\hline & \multicolumn{2}{c}{ RMSE } & \multicolumn{2}{c}{ Percentage Difference } \\
\cline { 2 - 5 } Segment Name & BOD & TP & BOD & TP \\
\cline { 2 - 5 } & $(\mathrm{mg} / \mathrm{L})$ & $(\mathrm{mg} / \mathrm{L})$ & $\%$ & $\%$ \\
\hline Segment 1 & 0.28 & 0.48 & 1.90 & 62.67 \\
Segment 2 & 0.27 & 0.61 & 1.79 & 63.18 \\
Segment 3 & 0.10 & 0.32 & 5.50 & 72.26 \\
Segment 4 & 2.64 & 0.29 & 26.72 & 80.33 \\
Segment 5 & 0.30 & 1.59 & 6.58 & 90.29 \\
Segment 6 & 5.25 & 1.84 & 22.08 & 87.74 \\
Segment 7 & 15.54 & 6.40 & 54.92 & 90.21 \\
Segment 8 & 0.75 & 1.25 & 1.79 & 76.21 \\
Segment 9 & 0.60 & 0.43 & 0.14 & 65.87 \\
Segment 10 & 0.74 & 2.01 & 8.25 & 91.57 \\
Segment 11 & 0.30 & 1.66 & 25.49 & 90.42 \\
Segment 12 & 16.20 & 2.11 & 12.35 & 91.54 \\
Average & 3.58 & 1.58 & 13.96 & 80.19 \\
\hline
\end{tabular}

The above parameters are obtained from trials and errors, and the reference value is based on the previous study (Larico et al., 2019; Moses et al., 2015). According to the calibration results, the value of the above parameters is relatively small. These parameters are highly affected by hydrodynamic, represented by the water velocity. The highest average velocity is 0.0487 meters per second and the lowest is 0.0058 meters per second for the upper segment (segment 1) and the lower segment (segment 12), respectively. Similar to the average velocity, the highest reaeration coefficient is in the upper segment while the lowest is in the lower segment. As a result, the selfpurification process argued relatively slow and require more advanced techniques to improve the process of self-purification. 
The output from calibration and verification are compared to the observed data and evaluated by RMSE and percentage difference. The mean RMSE for BOD and TP is $3.58 \mathrm{mg} / \mathrm{l}$, and $1.58 \mathrm{mg} / \mathrm{l}$, respectively, while the average percentage difference for BOD and TP is $13.96 \%$ and $80.19 \%$, respectively. Although the percentage difference is relatively high, the actual condition is small, with $1.32 \mathrm{mg} / \mathrm{l}$ for BOD and $0.65 \mathrm{mg} / \mathrm{l}$ for TP. This indicates that more data is required to evaluate the model. The summary of RMSE and percentage difference can be seen in Table 6. On the other hand, the relationship between observed and predicted BOD and TP load shown in Figure 3 and Figure 4, respectively.

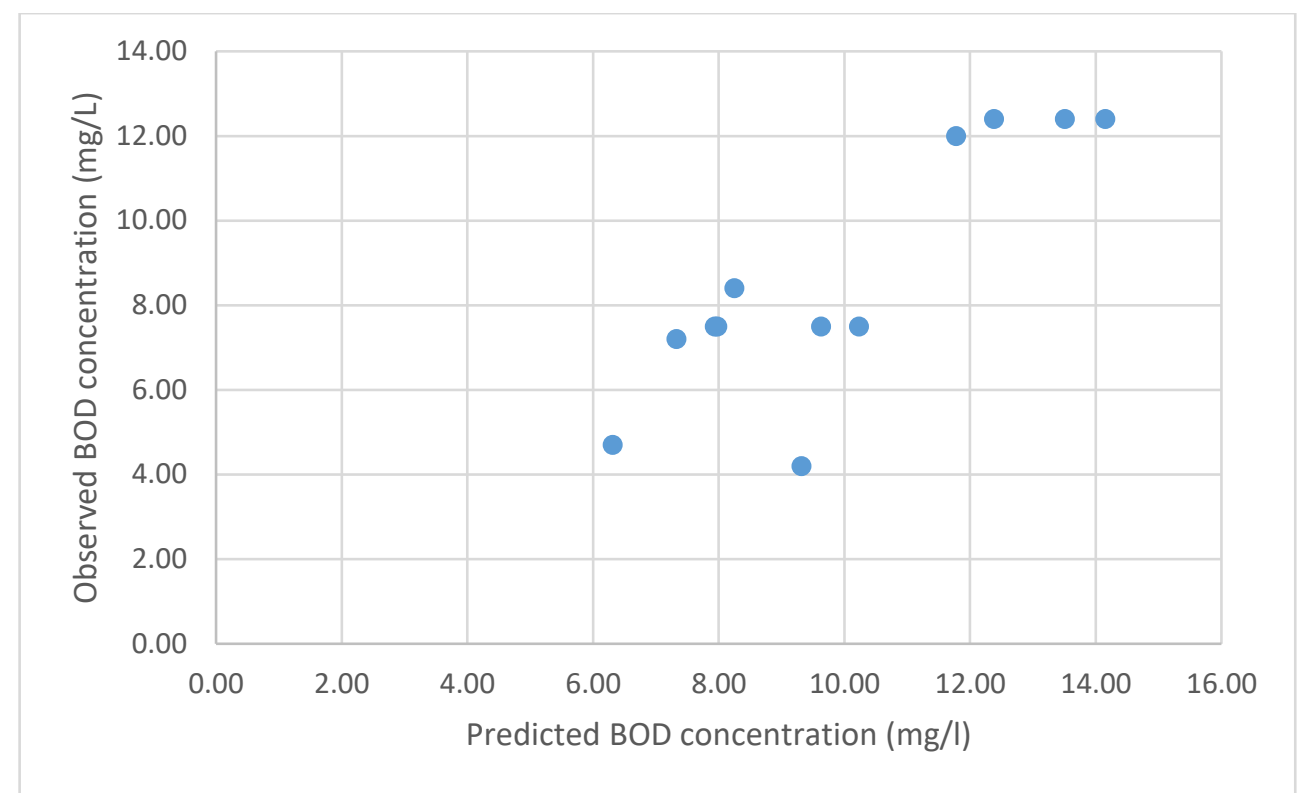

Figure 3. Relationship between predicted and observed BOD

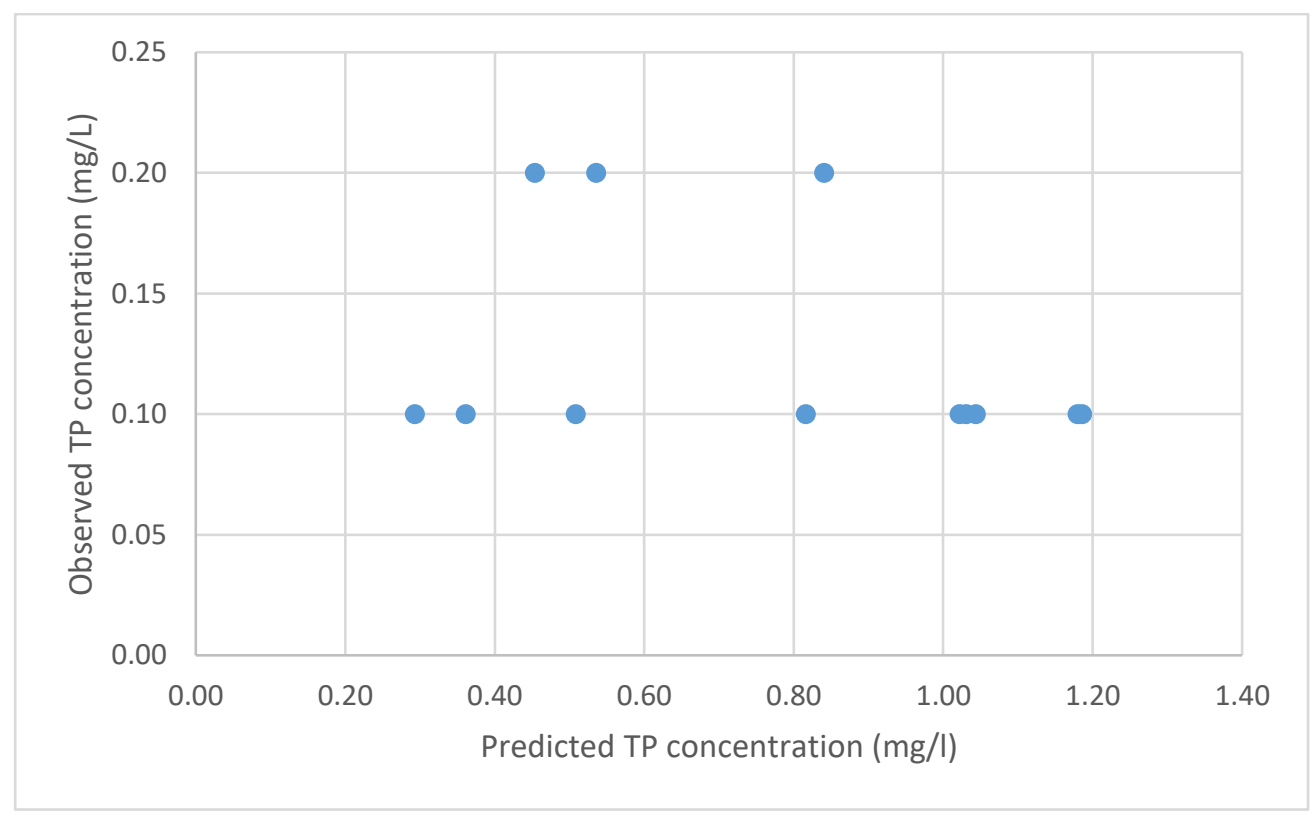

Figure 4. Relationship between predicted and observed TP 


\section{DISCUSSION}

Mass cleaning of water hyacinths take place in 2016, and several fish farms are no longer allowed to operate. As a result, the water in the dam is improved in the following year. As no further information regarding other pollutants such as domestic or industrial wastewater in the dam, this research assumed the mass cleaning also occurs in the domestic loads. Apart from mass cleaning, it is also found that the seasonal effects highly contribute to the improvement of water quality and hydrodynamic in Duriangkang Dam. As the population growth may increase the pollutant load, a restoration is suggested as the primary action to improve the water condition in any water body. In addition, monitoring and law enforcement must be applied in order to maintain the water condition.

Based on the simulation results, the calibrated load and the environmental parameters provided minimum RMSE and percentage difference value. In this study, the data for water observation are limited and not distributed evenly in each segment. The section with no observation data would then use the nearest observation data as the comparison. The average RMSE results for BOD and TP are $3.58 \mathrm{mg} / \mathrm{l}$ and $1.58 \mathrm{mg} / \mathrm{l}$, and the error value can be reduced if each segment has actual observation data. Despite the percentage difference value is relatively high, the actual difference is small. Therefore, more data is required for the comparison in order to evaluate the model. Due to the data limitation, the percentage difference is the only alternative to verify the findings.

The results from BOD concentration showed exceeding amount of domestic wastewater that regulated in the Indonesian Minister of Environment and Forestry No P.68/Menlhk/Setjen/Kum.1/8/2016. Based on the findings from BOD concentration $(54.02 \mathrm{mg} / \mathrm{l})$ and the observed water quality data, the dam is polluted and no longer classified as 2nd class of raw water. The results of this study may become the basis to pursue restoration to maintain the water quality in the dam.

\section{CONCLUSION}

The calibration process generates the value of $1.07-1.60$ day $^{-1}, 0.01 \mathrm{day}^{-1}$, and $0.04 \mathrm{day}^{-1}$ for the reaeration coefficient, BOD decay rate, and mineralization rate constant for dissolved organic phosphorus, accordingly. From 2016 to 2018, calibrated BOD loads are found to have the value of $3945.92 \mathrm{~kg} /$ day, $1165.07 \mathrm{~kg} / \mathrm{day}, 722.95 \mathrm{~kg} /$ day while the TP loads are $2258.04 \mathrm{~kg} / \mathrm{day}, 240.38$ $\mathrm{kg} / \mathrm{day}$, and $27.12 \mathrm{~kg} /$ day respectively. The BOD concentration based on the predicted domestic

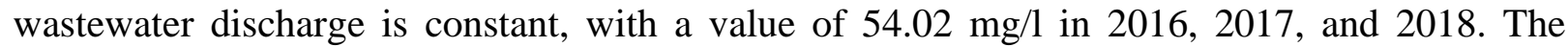
average RMSE results give a satisfactory result of $3.58 \mathrm{mg} / \mathrm{l}$ and $1.58 \mathrm{mg} / \mathrm{l}$ for BOD and TP. In addition, the average percentage difference also provides similar result of $13.96 \%$, and $80.19 \%$ for BOD and TP, respectively. Although the average percentage difference is relatively high, the average actual condition is only $1.32 \mathrm{mg} / \mathrm{l}$ for BOD and $0.65 \mathrm{mg} / \mathrm{l}$ for TP.

Future study suggested to measure the water quality from the upper rivers and the outflow of the Muka Kuning Dam. The actual load, discharge from domestic, and fish farms load are required to increase the results of calibration and verification. In addition, the sampling location must be evenly distributed along the dam. When the same place being investigated, a restoration should be take place both in Duriangkang Dam and Muka Kuning Dam in order to increase the water quality.

\section{REFERENCES}

Ambrose, R. B., Wool, T. A., Connolly, J. P., \& Schanz, R. W. (1988). WASP4, a Hydrodynamic and Water-Quality Model - Model Theory, User's Manual, and Programmer's Guide. In 
U.S. Environmental Protection Agency.

Balcerzak, W. (2006). The protection of reservoir water against the eutrophication process. Polish Journal of Environmental Studies, 15(6), 837-844.

Badan Pusat Statistik. (2015). Batam Dalam Angka 2015.

Badan Pusat Statistik. (2017). Batam Dalam Angka 2017.

Badan Pusat Statistik. (2018). Batam Dalam Angka 2018.

Bowie, G., Mills, W., Porcella, D., Campbell, C., Pagenkopf, J., Rupp, G., Johnson, K., Chan, P., Gherini, S., \& Chamberlin, C. (1985). Rates, constants, and kinetics formulations in surface water quality modeling. U.S. Environmental Protection Agency, 600, 3-85.

Connolly, J. P., \& Winfield, R. P. (1984). A user's guide for WASTOX, a framework for modeling the fate of toxic chemicals in aquatic environments Part 1: Exposure concentration. In U.S. Environmental Protection Agency.

Di Toro, D. M., Fitzpatrick, J. J., Thomann, R. V, \& Hydroscience, I. (1983). Documentation For Water Quality Analysis Simulation Program (WASP) And Model Verification Program (MVP). Proc Spie, 34(5), 4-10.

Ernst, M. R., \& Owens, J. (2009). Development and application of a WASP model on a large Texas reservoir to assess eutrophication control. Lake and Reservoir Management, 25(2), 136-148. https://doi.org/10.1080/07438140902821389

Flynn, K., \& Suplee, M. W. (2011). Using a computer water quality model to derive numeric nutrient criteria: Lower Yellowstone River. WQPBDMSTECH-22. https://deq.mt.gov/Portals/112/Water/WQPB/Standards/NutrientWorkGroup/PDFs/Yellow stoneModel/WQPBDMSTECH-22-DRAFTBasicEquate.pdf

Hariyadi, R. (2006). Pengaruh Pencemaran Limbah Industri dan Domestik Terhadap Kualitas Air Waduk Duriangkang. Jurnal Teknik Lingkungan, 7(3), 271-276.

Himesh, S. (2000). "Calibration and Validation of Water Quality Model". Technical Report CM 0002. CSIR Centre for Mathematical Modelling and Computer Simulation, May.

Larico, M., Johan, A., Medina, Z., \& Adolfo, S. (2019). Application of WASP model for assessment of water quality for eutrophication control for a reservoir in the Peruvian Andes. Lakes and Reservoirs: Research and Management, 24(1), 37-47. https://doi.org/10.1111/lre.12256

Mateus, M., Vieira, R. da S., Almeida, C., Silva, M., \& Reis, F. (2018). ScoRE-A simple approach to select a water quality model. Water (Switzerland), 10(12). https://doi.org/10.3390/w10121811

Moses, S. A., Janaki, L., Joseph, S., \& Joseph, J. (2015). Water quality prediction capabilities of WASP model for a tropical lake system. Lakes and Reservoirs: Research and Management, 20(4), 285-299. https://doi.org/10.1111//re.12110

Willy, Riyanto, A.R., Yudianto, D., \& Wicaksono, A. (2020). Application of TRMM data to the analysis of water availability and flood discharge in Duriangkang Dam. Journal of the Civil Engineering Forum, 6(1) 79-88. https://doi.org/10.22146/jcef.51521 